\title{
Astroscientistas A note from the organizers
}

Von: Carla R. Almeida

The organizing committee of Astroscientists is formed by Carla Rodrigues Almeida, Emmanuel Frion, Paola Delgado, Rodrigo von Marttens and Tays Miranda, who signed this blog post together. All of them at one moment or another were a Ph.D. student of Physics at the Federal University of Espírito Santo in Brazil, the institution that binds them together. They are also good friends and skilled researchers working on several topics of the Astrosciences.

Six months ago, we decided to turn our frustration with the current academic setback in Brazil, furthered by a political crisis and the COVID-19 pandemic, into something positive. Amidst a wave of anti-scientific agenda in our home country and the perceived growth in discrimination against minority groups, it seemed appropriate to honor Brazilian science and the female researchers working in our field with a conference to celebrate the International Day of Women and Girls in Science. The first edition of Astroscientists-a neologism referring to the physicists working on Astrophysics, Cosmology and Gravitation-was virtual and held mainly in Portuguese from February $8^{\text {th }}$ to $11^{\text {th }}$ of 2021. "Astroscientists, a Brazilian Meeting of Girls and Women in the Astrophysics, Cosmology and Gravitation", is our love letter to the historically-neglected female researchers of those fields who are currently working or have worked in Brazil.

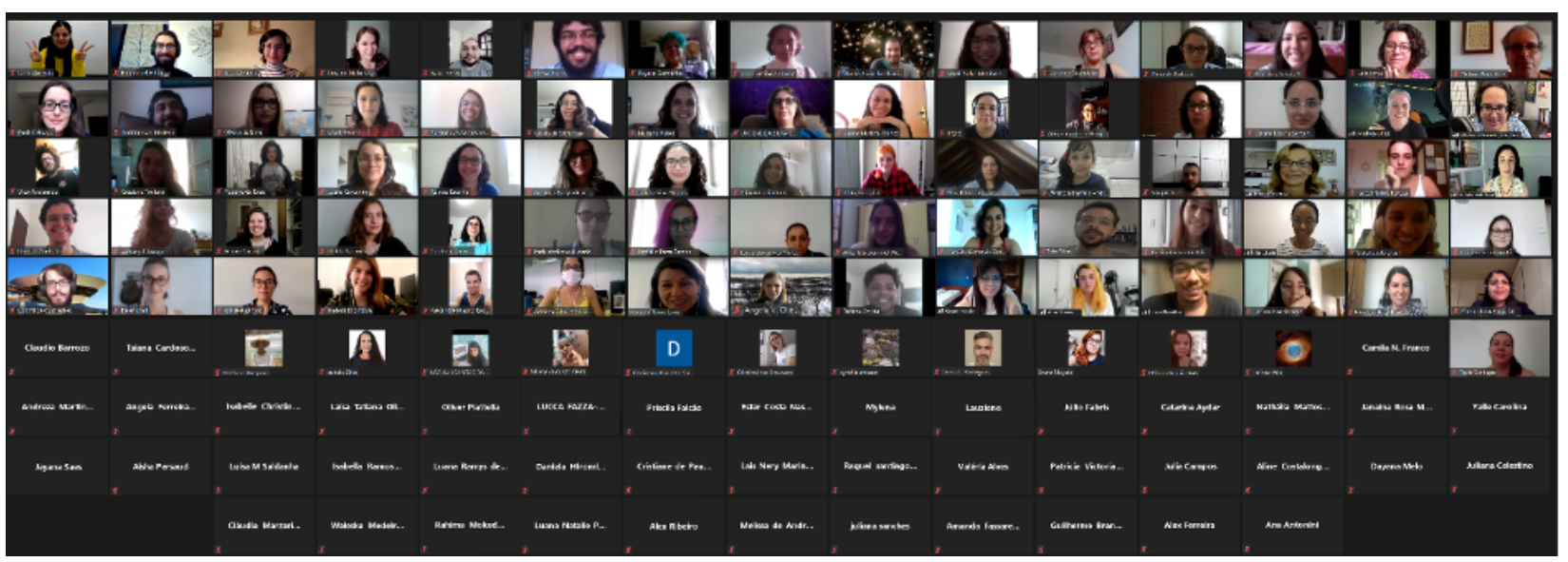

Photo: Official Zoom photo of the Conference, Carla Rodrigues Almeida

We are a group of early-career researchers working in different parts of the world and thus without a host institution to vouch for this event. Therefore, we benefitted from the support of the Institute for Advanced Studies in the Humanities (KWI), the International Ph.D. Program in Astrophysics, Cosmology and Gravitation (PPGCosmo), and the 
Brazilian Center for Research in Physics (CBPF) to validate our cause and to reassure the guest lecturers about the sincerity of our invitation. Astroscientists started as a humble idea that evolved and grew beyond our imagination. The political weight of this event became apparent to us in hindsight, when we were reminiscing about our organizational method. For the three women in the organizing committee, the struggle to give always $110 \%$ to achieve our goals in a male-dominated environment has become routine, but it was a new experience for the two male organizers. If we had failed, it would not be only a personal failure. It would send the wrong message to our community.

Even with the careful planning, we could not have foreseen this tremendous success. The enthusiasm of the participants and the high-quality talks given by our guests were overwhelming, adding to the pile of evidence that women can do science as well as their male peers if given the opportunity. One of our hardest tasks was to choose who to invite among too many talented researchers. In this matter, we prioritized diversity understanding there would be no loss in quality following this criterion. Our goal was to bring up the conference's theme in a sensible way, but without overlooking its political relevance. With this in mind, we included round-table discussions in the program to give voice to female scientists in important scientific and political matters, inspiring the next generation of girls and women in Astrophysics, Cosmology and Gravitation. On February $11^{\text {th }}$, the International Day of Girls and Women in Science, we welcomed last year's Nobel Prize winner Andrea Ghez for a special talk. We, the organizing committee, are still flabbergasted with her presence. It was an immense honor to listen to one of the four female scientists to ever receive a Nobel Prize in Physics speak at our modest conference. She is an inspiration for a whole generation of girls and women in science, and we cannot thank her enough for her participation.

Another point of discussion during the organization was how to approach the participation of men in this event. Astroscientists was a celebration of Women and Girls in Science and we understand this as a cause that should be and must be commemorated by men too. We opened the submissions for oral and poster presentations to everyone, but to keep it faithful to the theme we asked men to present the work of female scientists they admire. This information was explicit on our website and our social media. Nevertheless, the most frequently asked question was if men could also take part in the conference. We must have missed a target, since even those interested in honoring our invited guests were unsure of our goal, although we are not sure of what we could have done better in this matter.

From the very beginning, the registration of female participants outnumbered the male ones by a significant margin. For us, it was the first time we attended a physics conference with more female participants. It was a victory: given opportunity and a safe space, women can thrive in this environment. But it was bittersweet at the same time. This female/male ratio does not reflect the current scenario of the Brazilian Astrosciences, which is still predominantly a male field. Given the quality of the lectures, why was there so little interest from male researchers? This question remains open. 
Today, when Brazil is threatened by an anti-scientific menace, the success of Astroscientists gives us a ray of hope. There is still much to learn and improve in our society, but these small steps are the best way to move forward. This will be the first of many editions aimed at creating diversity, equity, and inclusion for the Brazilian scientific community. We are grateful for everyone who made Astroscientists possible. It was a collective victory.

SUGGESTED CITATION: Rodrigues Almeida, Carla; Frion, Emmanuel; Delgado, Paola; von Marttens, Rodrigo; Miranda, Tays: Astroscientistas. A note from the organizers, in: KWI-BLOG, [https://blog.kulturwissenschaften.de/astroscientistas/], 06.04.2021

DOI: $\underline{\text { https://doi.org/10.37189/kwi-blog/20210406-0830 }}$ 


\section{DuEPublico}

Duisburg-Essen Publications online

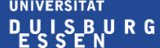

offen im Denken

Dieser Text wird via DuEPublico, dem Dokumenten- und Publikationsserver der Universität Duisburg-Essen, zur Verfügung gestellt. Die hier veröffentlichte Version der E-Publikation kann von einer eventuell ebenfalls veröffentlichten Verlagsversion abweichen.

DOI: $\quad 10.37189 / \mathrm{kwi}-\mathrm{blog} / 20210406-0830$

URN: urn:nbn:de:hbz:464-20210406-114411-3

Alle Rechte vorbehalten. 